\title{
T. COM 180: THE COMPANY MODEL
}

\author{
Don Precosky
}

\section{Background}

In January 1984 The College of New Caledonia introduced a rew technical writing course into its curriculum, T. Com. 180. The official calendar description of that course reads

This course provides students in career programs with the skills necessary for effective written and spoken communication in the business world. Students will be given extensive practice in writing clear and concise English, planning and researching business and/or technical projects, presenting reports in appropriate formats, and participating in interviews, in business meetings, and in oral presentations of research and results.

The course introduced two features which had not been a part of earlier technical writing courses at the College: the use of word processing as a tool for composing and editing, and the organization of class activities around the "company model".

The first time the course ran it was offered only to students in technology courses including Forestry, Electronics. Medical Laboratory, and Construction technologies. It was taught by two people, Paul Ramsey and Don Precosky. The classes met for three hours per week and were team-taught by the two instructors as they were feeling their way through a new approach. The second time it ran (January 1984) it was offered to the technology students and to business students as well. A third instructor, John Harris, was added and the sections were no longer team-taught (timetabling made it impossible), but full co-ordination was maintained. The students received the same schedule of assignments, grading criteria, handouts, and textbooks. The sections met for four hours per week; two hours were scheduled as lectures and two were labs. Most class meetings were held in the Technical Communications Skills Centre, a room containing, in addition to the standard issue desks, chairs, and blackboards, nine Apple Macintosh computers, two printers, a small reference collection, and two telephones. When the need arose, we also obtained video-recording equipment.

\section{The Company Model}

The main innovation in T. Com. 180 is that it is not run as a regular academic class, but as a mock company. We first heard of the 
idea from Jim Hamilton, who uses it at Okanagan College. Here is the description which we give the students:

Think of this class as a private consulting company. The company has been commissioned by a number of other companies in the community to do research for them and communicate the results of that research to them. The company will be divided into Divisions of four or five students each. Each Division will be working on one major project for a firm in the community.

The organization of our company is quite simple. We (your instructors) are your incredibly demanding company presidents. You are our extremely hard-working employees. We arrange contracts for consulting work, oversee the work of our employees, and provide them with assistance and advice when needed. We also evaluate the work done by members of the company.

Naturally, we expect you to keep us informed about your work. To that end, we will be asking you to communicate with us in both written and oral form. We will be asking for a project proposal and outline, minutes of Division meetings, progress reports (both written and oral), a bibliography of research, as well as a final formal report in both written and oral form.

We will also be communicating with you, both in writing and speech. Most formal work assignments and much important information will be provided in writing. In addition, we will be providing training workshops to assist you in completing your research project. These workshops will cover such topics as preparation and use of visuals in written and oral reports, interviewing skills, formats for memoranda and letters, letters of application and resumes, and use of Macintosh computers in production of written and visual material. These workshops will take approximately one-half of the scheduled sessions for Technical Communications 180 .

Toward the end of the semester your Division will produce a final report. The original of the report will be presented to a representative of the company for which your Division has been working; a copy will go to your presidents. Each Division will also deliver an oral report on its findings and recommendations. The audience for this presentation will include classmates, the company representative, interested members of the College faculty and administration, and us. If your final reports are acceptable to both the company representative and us, we will give you a favorable reference and wish you the best of success in future employment.

Although most do not have pertinent work experience, 1 the students take to the fiction of the company model quite readily. Their first task is to select a name for the company, something they dive into with relish. 
Their eagerness is an example of the primary value of the company model, which is that it overcomes the motivational problems which all technical writing instructors find in their classes. We have all heard objections such as "I don't like English" or "This is just another English course" or "My technical knowledge will get me ahead; writing doesn't count" or "What I write isn't real; it's just for the teacher to mark." By doing real projects for clients from their chosen fields, students quickly discover that they will have to write at work and that specialized knowledge isn't enough: they also need good communications skills. They have the added incentive that the course puts them in contact with a potential employer.

Another feature of the company model is that it achieves a level of task integration comparable to that achieved on a job. That is, on a real project a worker might have to write a proposal, memos, progress reports, notes from meetings, and a formal report, as well as give several oral reports. In a lecture classroom, assignments may seem to exist in isolation. Unlike some classes which may have some assignments which are simulations of "real" tasks, 2 the company model integrates a"1 assignments into a project which is not a simulation, but a piece of real-life writing which will be read by an audience beyond the classroom.

The students do two sorts of assignments: individual [:] assignments and group [G] ones. Some are written and some are orai. The list of the assignments, as it is given to the students, includes

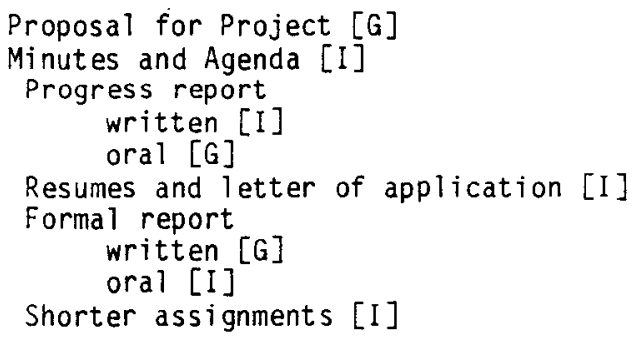

There is also a "President's evaluation" of each student worth $5 \%$ of the final mark.

Some of the assignments carry the students beyond the T. Com. Centre and the campus. They have to phone their client to make an appointment and then they must delegate members of their Division to go to the client's place of business to interview him or her. They also often use the phone to gather information from other sources and they sometimes must write "real" request letters to third parties. Some projects require students to conduct polls or interviews off campus.

As you can see, we try to make the course as close to "real" work as possible. The classes are run as meetings; assignments are given in 
memo form; the company name is used on internal communications; classes are run as meetings with students making reports and giving presentations; and there is a "Procedures Manual" which describes all phases of the course to students.

One particularly realistic feature of the course is the "firing option". Here is the description which appears in the "Procedures Manual":

\section{Getting Fired}

In every company there are certain mutual obligations between employer and employee. In our company the employer (your instructor) has an obligation to give clear instruction and direction, provide advice and assistance, evaluate your work fairly, and be available in the Technical Communication Skills Centre when scheduled. The employees (that's you) are expected to attend company meetings, complete assigned work on time, work cooperatively with the members of their Division, and generaliy behave in a responsible, professional manner. General expectations of employees have been outlined earlier in this manual.

If you fail to live up to your obligations, your employer has the right to "fire" you. If you are fired, you will no longer work as a member of a Divisional team. Instead, you will be required to complete a series of readings, exercises, written assignments, and examinations working on your own. You will not attend company meetings (where instruction takes place) nor receive assistance from your employer. Even if you complete all assignments satisfactorily, you cannot receive a final mark for the course above C+.

The instructor has to do a lot of work before the course begins. Most of this work involves lining up clients. He has to gather the names of likeiy participants; make initial phone contact to rouse interest; mail out written explanations of what is wanted; and (this is critical) help the client formulate a suitable topic which is not too large, not too small, and is of some real use to the client's business (see List 1: Representative Report Titles for T. Com. 180). It is, indeed, a daunting exercise in technical communication. We have found that colleagues in the business and technology programmes are a most reliable source of contacts. Our institution has advisory committees for its programmes and we have found their members to be good clients for the course. Generally, local business has been very helpful. We were able to secure about fifty volunteer clients in 1985 (see List 2: Typical Clients of T. Com. 180). 


\section{LIST 1: REPRESENTATIVE REPORT TITLES FOR T. COM. 180}

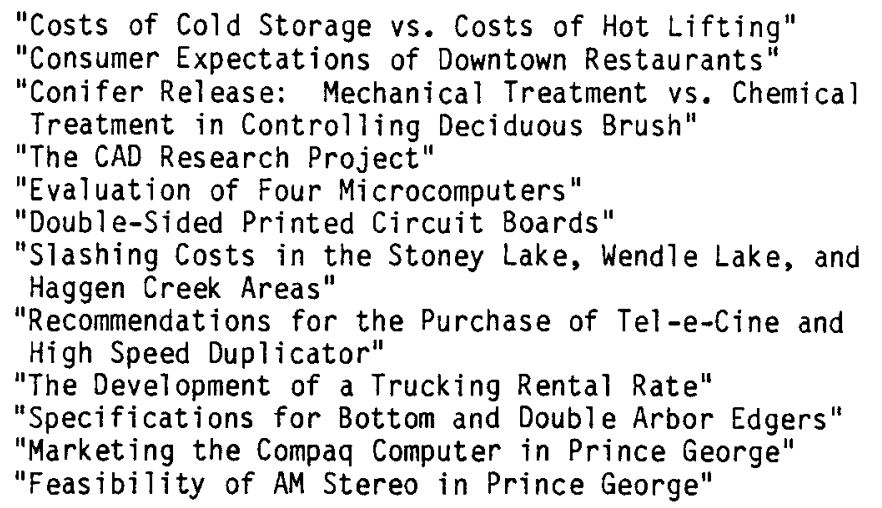

LIST 2: TYPICAL CLIENTS OF T. COM. 180

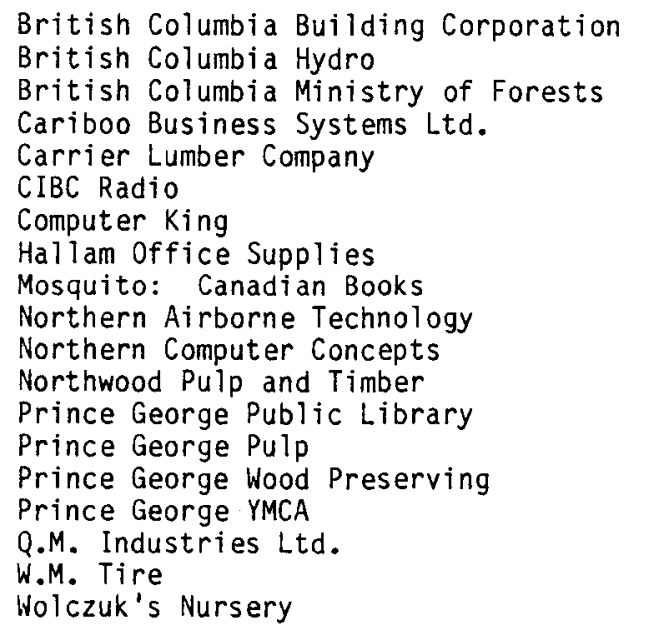

Running the Company

Each "company" has four hours of meetings per week. Two hours are devoted to curriculum matters where the president explains how to perform the required writing tasks. Time is also set aside for the individual divisions to meet and work on their projects. The president sits in for a brief time at each meeting. The remaining two hours per week are lab time, when students use Macintoshes to enter, edit, and print their written work. The president is available to help them with 
their planning, writing, and revising. He also helps them with any problems which might come up with their use of the word processing software, MacWrite. Instructional and lab meetings are scheduled in different rooms but the timetable is arranged so that the Lab is not booked during instructional time and vice versa so that groups can work at an independent but supervised pace. At any one time some divisions might be in the lab editing and printing a document while others might be in the quieter classroom holding a meeting. In order to keep the situation controllable T. Com. 180 has a maximum class size of 25 .

\section{Word Processing}

In the first year of operation we used the Bank Street Writer word processing programme running on Apple IIe's. We had no graphics software. The Bank Street Writer is simple to use, but gains its ease of operation at the expense of flexibility and power, especially in formatting capabilities. One feature which I liked was the way it separated editing and creating into two different modes. This structure reflects current thinking on composition methods. 3

In the second year we used the Apple Macintosh with MacWrite word processing and MacPaint graphics software. It was a much better system for our purposes because the students need no previous experience or training in the use of computers. The only serious drawback was the slowness of the printer. The Macintosh is "icon" driven, which means that the students control the computer by manipulating a pointer on the screen, positioning it on a picture or word which represents the task they wish to perform, and pushing a button. The general operating procedure of the machine is easily learned through the selfguided tour which comes with it (a co-ordinated disk/cassette tape presentation). MacWrite is a particularly good programme because of its flexibility. As Bryan Pfaffenberger notes in the most recent issue of Research in Word Processing Newsletter,

the program offers some attractive features, including onscreen display of the Mac's standard set of foreign language and mathematical characters, the ability to blend graphic images with text, printer font selection (and onscreen display of the selected font), and a printer control system that (with the Apple Imagewriter printer) produces a high-quality printout that corresponds precisely to the video display. 4

It, too, comes bundled with a co-ordinated disk/cassette tape guided tour. The students were entering text within one hour of their first turning the machine on. 
Word processing has a number of things going for it which make it useful in any writing/composition course. These include improved generation of ideas, improved ease of revision, greatly improved extent of revision, and enhanced appearance of the completed work. Because of the ease in composing and editing and also because of the novelty factor of the machines, we noticed an increase in student motivation in the course as compared to our former classroom course. The Centre was always busy during 'drop-in' times. It didn't officially open until 8:30 but I have had students at my office door as early as 7:30 asking if I would let them in. There were requests for evening access to the machines and for lunch-hour access. During spring break students were still diligently typing away. And, when they thought we weren't looking, they used the Macintoshes to prepare essays and reports for other courses.

\section{Conclusion}

T. Com. 180, with its use of the company model and word processors, is a lot of work but the work pays off for the students and the teachers. It's fun to teach and the students learn to perform real-life writing tasks using the technology that will play a large part in their workinglives.

\section{NOTES}

$1_{A}$ survey of current T. Com. 180 students reveals that $26 \%$ had what they felt was pertinent job experience. The survey also shows that they range in age from 18 to 44 with an average age of 23. Of those with pertinent job experience the length varied from 25 years to 1 month with an average of 3 years. Interestingly, only $35 \%$ of the students surveyed had come into their programme directly from high school.

2See, for example, Bruce Speck, "A Simulated Approach to Business Writing," The ABCA Bulletin 46(December 1983), 38-41 for a description of such a simulation approach.

3 See Peter Elbow, Writing With Power (New York: Oxford, 1981) and Linda Flower, Problem-Solving Strategies For Writing, Second Edition (New York: Harcourt Brace Jovanovich, 1985).

4Bryan Pfaffenberger, "A Typology of Word-Processing Programs," Research in Word Processing Newsletter 4, no. 2 (February 1986), 8-9.

Donald A. Precosky teaches technical communication at the College of New Caledonia, Prince George, British Columbia. 